\title{
Where are the women? Perceived Barriers to Engineering Education: Ex- ploring the feminist influences on curriculum in British Columbia and on the career choices of women with high school physics credit
}

\author{
Katherina V Tarnai-Lokhorst P.Eng., FEC, Camosun College
}

Katherina Tarnai-Lokhorst, P.Eng., BASc, MBA, doctoral student

Kathy is a Mechanical Engineering Instructor at Camosun College. She received her BASc from UBC in 1987 specializing in aerodynamics and her MBA from the University of Phoenix in 2007. Kathy is pursuing her Doctor of Social Science at Royal Roads University, researching educational philosophies and practices prevalent in high school and introductory university physics and math courses, and developing recommendations to increase gender diversity in engineering education and the engineering profession. Kathy is an elected Councillor for APEGBC (the Association of Professional Engineers and Geoscientists of British Columbia), has served on several educational and governance committees at Camosun College, and is a qualified restorative justice facilitator, peer coach and liturgical musician. 


\title{
Where are the women? Perceived Barriers to Engineering Education: Exploring the feminist influences on curriculum in British Columbia and on the career choices of women with high school physics credit
}

\begin{abstract}
The population of engineers is insufficient to meet long-term demand; although immigration is boosting the numbers and adding diversity to the mix, women are still severely underrepresented 1,2 . The recruitment of women into these programs is a clear opportunity to meet industry demand for engineers. Young women occupy an increasing percentage of the seats in high school physics classrooms ${ }^{3,4}$. This paper presents evidence from the British Columbia school system depicting trends in the number of young women completing high school physics and the careers they choose to pursue. The data is interpreted through a review of the history of feminist influences on education in British Columbia and on Canadian society.
\end{abstract}

Keywords

Engineering Education; Gender; Stereotypes; Feminist Influences; STEM

Introduction

Young women occupy an increasing percentage of the seats in high school physics classrooms yet they do not, for the most part, enter post-secondary programs in engineering or physics ${ }^{3,4}$. In this paper, I explore the possible ongoing societal reasons for this phenomenon by reviewing, decade-by-decade, the history of feminist influences on education in British Columbia and on Canadian society. Furthermore, I present data trends from the British Columbia school system that may correlate to societal shifts.

Feminist activism has had pervasive influences on society, far beyond the acquisition of a desired right or privilege ${ }^{5-8}$. I first describe how the three waves of feminism have influenced public school and post-secondary curriculum in British Columbia, and how those changes may correspond to the continuing gender gap in post-secondary education for STEM areas: science, technology, engineering and mathematics. Next, I present the analysis of four decades of student data collected from a comprehensive community college in British Columbia. The purpose of this analysis is to determine the percentage of girls who successfully completed high school physics credits and to present a trending view of their career choices. The analysis shows how those choices have changed over time, as related to the feminization of curriculum in the BC high school system.

The three waves of feminism were very different with respect to activism and urgency. The first wave consisted of increasing participation of women in political and social life and rising levels of education. Women acquired the right to vote and started working outside of the home in teaching and clerical occupations. The second wave is noted for the militant activism of the women's liberation movement and, in Canada, the 167 recommendations of the Royal Commission on the Status of Women, resulting in legislated equality for women in work, 
education and law. The activism of the second wave of feminism produced the majority of curriculum feminization and raised concerns about the effect of feminized curriculum on boys. The third wave, also called post-feminism, is a time of confusion for most girls and women who believe they live in a society of equality but experience sexism in many obvious and hidden ways. British Columbian curriculum documents no longer mention feminist requirements but focus on aboriginal and racial diversity, reflecting the post-feminist culture that women are equal and sexism no longer needs mentioning. The post-feminist constructs of Girl Power and Successful Girls ${ }^{9,10}$ send the message that girls can do and have anything, yet barriers to engineering and other careers in the physical sciences continue to deter women from entering those careers.

History textbooks are good indicators of how well social knowledge is transmitted to younger generations and, according to Jane Gaskell ${ }^{11,12}$, textbooks from the first wave rarely included references to women's experiences. The early feminists attempted to initiate changes to the curriculum in their role as teachers, setting lesson plans and writing texts to introduce students to issues relevant to life in the home and building a foundation for - or maybe driving - the second wave of feminism ${ }^{13-18}$. Coinciding with racial activism, the second wave was replete with militant affirmative action ${ }^{19}$, which alienated some from the growing women's liberation movements across Canada, the United States and Britain ${ }^{20-22}$. History textbooks in use during this time reflect the extreme positions: while most authors held on to androcentric depictions of major events, a included many references to women's contribution to historical events ${ }^{14}$. The third wave of feminism, also referred to as post-feminism, is marked by a mood of inclusivity, welcoming full diversity and fighting not for women's rights but rather for equality and fairness for all sub groups ${ }^{10}$. Expanding on the observations of Pomerantz and Raby, if one could ask a female engineer or physicist today, she would likely say she self-identifies without a gender tag because she will have grown up in a society that values of diversity and multiple standpoints, and where all things are possible for all people. Yet she will also likely say she has experienced direct sexism at some point in her life - through disparaging actions or comments at work or discouragement at home - and felt powerless to overcome it ${ }^{9}$.

The impact of societal influences on career choice is becoming clearer: data from the British Columbia (BC) school system indicates curious trends. Electronic data storage in BC Ministry of Education in the 1990s but data is stored for 55 years. I am in the process of collecting the electronic data set from the ministry and the photocopied data set from the BC Archives. Fortunately, through my affiliation with a college in BC, I have received permission to view the data set of all students at Camosun College since 1972. This data set will be analyzed by April 2015 and the results included in this paper.

\section{The First Wave of Feminism}

The first wave of feminism began in the late 1870s and lasted through to 1940 with passing of the women's suffrage bill in Quebec ${ }^{19}$. This period is marked by a rapid growth of women's organizations, and an increasing female social and political activity.

Women attained the right to vote as early as 1916 in some provinces, moving women's political actions from the sitting room to the public realm ${ }^{19}$. Yet, Clark ${ }^{14}$ notes that at the turn of the $20^{\text {th }}$ century many Canadian women were not simply housewives but true homemakers, responsible 
for producing all of the needs within the home. As settlers, women took care of the domestic duties ${ }^{14}$ and were socially and politically active in the schools, churches, and organizations like the Women's Christian Temperance Union, the International Order of the Daughters of the Empire, and the National Council of Women of Canada (Anderson, 2014). These organizations, according to Anderson, focused on improving the broader society by caring for the ill, raising funds for shelters and orphanages, and interacting in the political sphere; these influential women were highly engaged in their social work, and coordinated their efforts to claim civic rights for women. The first wave of feminism was a period of women's increasing participation in the politics of society ${ }^{12}$.

Women's duties in and out of the home complemented the contributions of working-class men who were farmers or labourers. Education was readily available in Canada and women were excellent students so that "by 1890 many Canadian universities opened their doors to women, albeit reluctantly" 6 . Most universities set quotas to limit the number of female students accepted. However, levels of education rose for men and women, resulting in rising demand for skilled workers ${ }^{5}$. Between 1910 and 1940, the number of clerical jobs rose quickly; when the men left to fight in World War I, working women filled most of these positions. When a woman married, she typically returned to the home to care for the family and engaged in unpaid socially oriented volunteer work.

As time passed, women's education levels continued to rise. Women were excellent teachers and in greater demand than male teachers who were more focused on teaching and more willing to accept lesser pay. Rebecca Coulter and Christopher Greig ${ }^{13}$ quote the 1908 Alberta Department of Education as saying men lack “one or all of the three G's: Go, Grit and Gumption” in comparison with women. Male teachers tried to attain sanctioned pay discrimination in teaching, so they could be recognized as distinct from female teachers and achieve professional status, restricted to men at this time in history. Unfortunately for them, society was not prepared to recognize male teachers for choosing to work in what was fast becoming a women's career ${ }^{23}$. Still, men were paid more $-\$ 487$ per month compared to the average woman's salary of $\$ 130$ per month - and women were willing to be "seen as rendering a service out of love and...not expect high levels of remuneration or autonomy" 13 .

During the second industrial revolution, men moved into manufacturing jobs, leaving more clerical positions to educated women ${ }^{5}$. Women were encouraged to pursue these clerical positions as they were deemed suitable feminine roles. In fact, clinical experts of the 1940s and 1950s studied and identified women's best qualities as "passivity, nurturance and concern for others [while downplaying] intellectual achievement and mastery needs" ${ }^{12}$. Women were encouraged to cultivate these traits as assets for clerical work.

Interestingly, textbooks of the time rarely mentioned women's contributions to society. Penny Clark ${ }^{14}$ reviewed the history textbooks that were either required or recommended by the BC Ministry of Education, tracking references to women's experiences in order to measure the influence of feminism on curriculum. The books in use in the early $20^{\text {th }}$ century only mentioned a woman if she was a queen commanding an expedition or a heroine like Laura Secord or, perhaps, one of the filles $d u$ roi, sent to New France to be "a nice little wife to make things pleasant" 14 . Otherwise, women were not mentioned at all. Androcentric depictions of history create the sense that women are peripheral to history or were deliberately overlooked. This is not the case, 
according to Clark, but rather an indication that the questions used to guide authors in creating the textbooks did not relate to women's contributions.

This assertion of Clark's is apparent in BC curriculum guides and historical data sets that have not aggregated gender information with science education. Gender issues first become a focus for $\mathrm{BC}$ curriculum designers later in history.

\section{Post World War II}

From the time that women won the right to vote, they began participating in government as elected members. Women's education rates greatly increased but discrimination was rampant: universities set quotas to limit the number of women permitted to register, managers used sexist hiring practices and laws were biased towards men ${ }^{24}$. In response to rising concerns, the Canadian government established the Royal Commission on the Status of Women in Canada in 1967 to examine women's place in Canadian society. In 1970, the Royal Commission presented 167 recommendations to recognize and foster the rights of women in employment, education and law ${ }^{19}$. Women's groups, coalitions, and liberation movements thrived in their work for the equality of women. Women entered the paid workforce in earnest, representing $32.7 \%$ of workers by $1970{ }^{14}$. These same surveys indicated women concurrently performed most or all the work in the home.

Support for the feminist movement at this time paralleled Canadians' rising tolerance towards races and creeds, which some authors suggest was in reaction to "Hitler's racism, the decline of close ties to Britain, and the impact of the American Civil Rights Movement",. Donald Wilson quoted in ${ }^{14}$. Canadian nationalistic pride increased dramatically in support of events like the very successful world exposition in Montreal and the election of the charismatic Pierre Elliot Trudeau as Prime Minister and history books were quickly rewritten to add Canadian quotes and references for BC schools ${ }^{25}$.

Until the Royal Commission published its recommendations, however, the feminist influence on curriculum was low ${ }^{12,14}$. In the 1950s and 1960s, few textbooks included discussions about the contributions of women to history, but still, only if they were royalty or writers of note. As the women's liberation movement and other coalitions gathered momentum, however, curriculum changes were more dramatic. Resistance arose against the feminization of curriculum because of beliefs that a "feminized school environment that denied boys' natural way of being was turning boys into sissies" $"$. Sociologists, male and female, advocated for more male teachers in the classroom, to make schools more hospitable to boys, but only of the "right kind": a "virile, rugged, manly man, one who could remasculinize boys by providing a hegemonic model of masculinity". After all, the wrong kind "may be worse than women"13.

Still, through the 1970s, the Canadian women's movement made concerted efforts to change the public school system in British Columbia. "Equality between the sexes became a legitimate policy issue, debated in schools, school boards, ministries and teachers' federations" 26. Rewritten and new textbooks were screened for appropriate portrayals of women, and "women's history and novels by feminists, even the occasional women's studies course, were added to the curriculum",26. 
Some academic writers of the time expressed concerns that women's issues were supplanting legitimate historical content ${ }^{15,25}$. However, the Royal Commission was clear in its recommendations that were formulated after reviewing elementary reading, social studies, mathematics and guidance texts, concluding: "This analysis of sex role imagery ... clearly indicates that a woman's creative and intellectual potential is either underplayed or ignored in the education of children from their earliest years"19.

Naomi Weisstein's 1969 lecture enabled the societal realization that gender roles - definitions of what women need and want - are psychological and social constructs:

With this realization, feminist educators began to take an activist stance toward curricular and pedagogical reform. During the 1970s and early 1980s they struggled to integrate the study of women and minorities into existing courses, initiated women's studies programs, and mainstreamed women's studies course. ${ }^{16}$

There was no consensus, in the 1960s and 1970s, about what a woman's role should be, but the Royal Commission provided official sanction for women to make their own decisions about their future. Some looked for work outside the home, some saw a woman's role was to work inside the home but in either case the work was valued lower than men's work ${ }^{12}$. This confusion was passed on to girls:

In sum, girls are told to be obedient and do what the school requires. But if they really succeed at this, they are contradicting another feminine imperative, which is to allow males to win. ${ }^{12}$

The conflict was more apparent when women adopted both male and female roles: Pomerantz and Raby ${ }^{10}$ give the example of a woman as scientist, who has role expectations normally aligning with male expectations and role expectations normally aligning with traditionally female expectations. This is the "superwoman" construct of the second wave of feminism, that women can "both [work] and [raise] a family without compromise on either front ${ }^{10}$.

Men's place as teachers continued to be challenged through the second wave of feminism. A homophobic fear pervaded masculine society and teaching was seen as effeminate ${ }^{13}$. Androcentric comments made during the first wave of feminism continued to surface at salary negotiation tables: "teaching cannot be a profession while women outnumber men". But at the same time, Coulter and Greig continue, women were less motivated to move into leadership positions and more willing to accept lesser pay. Women with a university degree were earning an average annual salary of $\$ 11,363$ while men with equal education earned an average of $\$ 20,337$. The differences in average wages were equally distinct only a high school diploma: $\$ 5,766$ for women, $\$ 12,085$ for men ${ }^{27}$.

While "discrimination prevents [those] women who aspire [for advancement] from achieving" 12 , the notion that women do not pursue leadership positions because they do not aspire to them is more insidious: "there is a prevailing view of women as passive, emotional and scatterbrained... [that is] usually elaborated into a role expectation"12. High school guidance counselors perpetuated this erroneous belief by making course recommendations based on stereotypical assumptions about which careers would be appropriate, a significant practice to ensure "categories of gender, class, and race are reproduced in the school",23. Gaskell's research found 
that $84 \%$ of students in high school believe they are following educational and work paths of their own choosing yet "gender divisions in the school curriculum correspond to divisions in the labor force, just as class divisions do". While students had the ability to make their own career choices in the 1970s, teachers tend to persuade them to a sexist course of study.

In this way, "schooling can help a girl, relative to other girls, but it is not effective in overcoming the group differences between males and females" ${ }^{\prime 27}$. Women with business degrees worked clerical jobs while men with business degrees worked in management. Gaskell describes how parents and friends often gave the erroneous information that there is high demand and easy opportunity for careers similar to their own, thereby perpetuating trends of gendered careers. After all, the consensus was if women aspired to high achievement, they would pursue high achievement, regardless of discrimination ${ }^{12}$. Canadian society began to overcome some of these patterns and misconceptions in the third wave of feminism.

\section{Post-Feminism? The Third Wave of Feminism}

By the 1980s, women's work is concentrated in a few occupational areas: "one-third third of them are in clerical jobs; the rest are mostly in sales and service jobs and in teaching and nursing...more likely than men to be at the bottom end of the hierarchy of responsibility and power" ${ }^{\prime 2}$. Over $41 \%$ of women were engaged in paid work ${ }^{14}$ yet women continued to reflect the aspirations of their parents. Educational reformers increased their efforts to "address the goals, direction and strategies of feminist curriculum change" ${ }^{\text {"16 }}$.

Predictably, educational designers had a difficult time reaching consensus ${ }^{16}$ : debates ensued about whether to reconstruct curriculum to incorporate women's issues and enrich existing curriculum, deconstruct existing curriculum to transform it, or develop entirely new stand-alone courses. Several independent curriculum development teams began work across North America, like the New Jersey Project. This 1986 conference developed an inclusive curriculum that began as distinct women's studies and evolved into curricular integration of race, ethnicity, class and gender, introducing both content and methods. By 1996, the project grew to involve more than 100 faculty members in two- and four-year higher education institutions; it was followed by the Curriculum Mainstreaming Teaching Initiative that involved faculty from New Jersey, Maryland, Massachusetts, New York, Illinois, California and Tennessee.

History textbooks in British Columbia tended to add content about women's issue in sidebars and asides from the main text. This "filler feminism" trivialized the contributions of women and depicted a subservient, lessor role for girls ${ }^{14}$. Elementary book authors were better at acknowledging the toil of women in Canada, Building our Nation but the secondary school texts then belittled their involvement with negative imagery of "women laughing and whispering together" during historical events, according to Penney Clark ${ }^{14}$. The Canadian provinces and territories commissioned text books that varied in their incorporation of women's issues, some providing broad coverage and others presenting women as 'larger than life' and 'tough as nails', a skewed representation difficult for girls to emulate.

In the 1990s, academic authors became more outspoken, using science to support the suggestion that "social inequalities have a biological basis or are genetically inherited and thus natural, right and good" ${ }^{28}$. Women are caught between sexism and post-feminism, which already implies the 
need for feminism is over. Constructs like 'Girl Power' and 'Successful Girls' create the image that social inequality no longer exists, so the need for political action is over ${ }^{9}$. However, the American Association of University Women, in their 2008 report, note that girls "in North America continue to face sexual harassment and sexual violence, particularly in the early years of high school"'.

The struggle against sexism in high school is perpetuated against teachers and students. Female teachers continue to experience sexist innuendo and sexist comments from male colleagues and students portray women as sexual physical beings ${ }^{29}$. Yet girls in the 1990s outperformed boys on tests and college entrance examinations and successfully competed with them for professional employment ${ }^{9}$. Academic researchers begin to explore why, following these feminist and government interventions throughout the late twentieth century, "boys are now struggling to keep up. Embedded in the Successful Girls discourse is thus a double form of gender reversal"".

Persisting stereotypes, that mathematics is a male domain, augment other factors that research indicates influence girls' success in the subject: the expectations teachers have about their students, the students' prior experiences in math, and the gender of their teachers ${ }^{30,31}$. More important, according to Dorothy Smith, Paula Bourne and Liza McCoy ${ }^{32}$, is "the school's 'hidden curriculum' that teaches girls that they are less important than and subordinate to boys -thus creating among girls an inner sense of inferiority that is self-silencing".

Several longitudinal studies in various countries confirm the hidden curriculum and the specious perception of boys' mathematical ability or talent, which are readily contradicted by test scores 33-39. Girls' motivations for achievement, however, were not affected by these hidden agenda prevalent in the STEM fields: "women who initially aspired to science-related careers but then shifted to non-science interests a decade later had aspirations that remained as prestigious as their original, science-related aspirations (e.g., lawyer)", Qing $\mathrm{Li}^{31}$ notes. Li goes on to say that most teachers are idealistic in their educational philosophy, believing it to be a "liberating and democratic influence". However, in practice, mathematics teachers in her study still reinforce traditional behaviours and occupational pathways for their students, regardless of gender or where their interests or talents lie. In fact, they often "seem to actively discourage nontraditional female interests.

A multinational conference in Vancouver, British Columbia, attracted educators from the US, Canada and Australia interested in fostering "dialogue that would bridge the gap between academic research and school practices", assessing "how feminist research could enrich the [public] school's subject matter disciplines" ${ }^{\prime 16}$. Very different from the American consortia of the 1980s, at this conference full consensus could not be reached, including the use of the term 'enrichment' in the conference invitation. When the attendees broke into smaller workgroups, they were then able to pursue their unique agendas and developed valuable insights useful for "a wide range of educators, students of curriculum theory, and organizers of post-secondary and public school curriculum reform projects" ${ }^{\prime 16}$.

In the new millennium, Donatille Mujawamariya and Amani Hamdan reviewed the Ontario Science and Technology Curriculum tested it for diversity. The curriculum was found to be meeting feminist criteria but lacking in aboriginal inclusivity ${ }^{17}$. Racial and gender balance are necessary in curriculum, according to the Ontario school board, because "students [are] more 
likely to succeed if their own racial, ethnic, and cultural identity is reflected in the classroom" ${ }^{\text {. }}$. Reviews of both the Ontario and British Columbia science curricula rarely mention gender and do so only to indicate that there were little or not differences in achievement between genders through the $1990 \mathrm{~s}^{40}$.

A transition study of rural schools in British Columbia found that women had a positive perception of their learning environments than their male classmates ${ }^{41}$. Both groups indicated that they found higher education learning environments to be less favourable than those they experienced in high school. Interestingly, Jennifer Shapka's research found Canadian women responded negatively to implications that there are barriers to attaining their educational goals ${ }^{33}$. Rebecca Raby and Shauna Pomerantz assert this is because scholarly women constantly maintain a balancing act between academic success and conforming to conventions of femininity and, therefore, do not recognize that barriers exist ${ }^{42}$.

The post-feminist constructs changed again in the 2000s and girls reported seeing themselves as empowered amidst contradictory sexist experiences:

[The participants in Pomerantz and Raby's study] spoke of themselves as empowered girls who have the world at their fingertips. But this feeling of optimism is contradicted by experiences of sexism both in and out of the school, and the belief that they will have to do better than boys throughout their lives just to be seen as equal. ${ }^{10}$

The messages of Girl Power and Successful Girls from the 1990s, that girls can do, be and have anything they want and that they are surpassing boys in the schools and work-places, "have made naming sexism in schools difficult for girls because they are now seen to 'have it all'... [and have made] cries of gender injustice appear not just unfounded but implausible" ${ }^{\text {" }}$. The post-feminist constructs mislead girls into thinking they shouldn't be experiencing the sexism that they are experiencing, so "the only person to blame when things go wrong is the girl herself"'. The constructs of gendered behaviour are expected of boys, too: a cultivated behaviour that is aggressive, competitive and compulsorily heterosexual ${ }^{42}$.

What does this mean for girls in physics?

Although curriculum seems to finally be at a place of gender inclusiveness ${ }^{40}$, teachers may in fact need some time to catch up. Studies by Jane Gaskell found that high school guidance counselors continue to encourage girls to pursue the quick path to clerical jobs ${ }^{27}$ and Qing Li demonstrated that teachers of mathematics continue to favour boys in the classroom ${ }^{31}$, so active research that involves physics teachers may be the best way to introduce new ideas to the adults who most influence the career choices of youth in high school.

Many of the larger engineering schools, the University of British Columbia, The University of Toronto and Waterloo University, reported record percentages of up to $30 \%$ women in their first year classes in September $2014^{1,43}$. Interestingly, they all endorse outreach programs to high school and middle school girls. These external programs, like Go ENG Girl and the Canadian Association for Girls in Science, CAGIS, are girls-only, activity-based programs led by young, vibrant, non-threatening and personable volunteer scientists. These programs follow up with past 
participants and report that significant numbers are pursuing science careers when they get older $^{44}$.

The brunt of feminist curriculum changes came out of the second wave of feminism. Most of those changes, however, mostly by inserting women's issues into the existing curriculum as sidebars or added text boxes or, alternatively by adding entire streams of women's studies courses and programs ${ }^{16}$. It is only in recent decades that new research has focused on how girls prefer to learn and what they need in order to feel safe to explore new and uncomfortable content ${ }^{32,42,45}$. For example, Alison Little ${ }^{46}$ determined, through their pilot teaching program in single-sex schools, that girls prefer working in small groups with practical hands-on activities like poster projects, presentations and discussions. Based in the School of Engineering in the University of Tasmania, the researchers' project goal was to attract girls in upper primary and secondary schools to engineering studies; in the process, they found that specific types of activities helped girls connect better to the physical sciences: "practical experiments and building things"46.

In mixed-gender classrooms, however, boys usually assume the active roles, a stereotype that is established as early as kindergarten ${ }^{44}$. When girls are left to take on the passive role of notetaker, they disengage from the lessons, and lose both confidence and interest in STEM ${ }^{47}$. This is not to say that single-sex schooling is the answer, because there are too many uncertainties surrounding the transition from single-sex to mixed-gender situations with the "reduced opportunities for cross-sex socialization" "47. Girls still tend to feel a decline in self-esteem and self-confidence during high school, both of which are predictors of decreased interest and competency in math ${ }^{33,34,48}$. Jennifer Shapka and Daniel Keating ${ }^{45,47}$ admit that many researchers have explored the benefits of single-sex and mixed-gender classrooms and schools, but controlling for multiple confounding variables, like socio-economic standing and prior achievement, has proven difficult. They recommend, therefore, that coeducational schools establish same-sex science classes to capture the best of both worlds: enabling girls to gain confidence and experience in physical sciences and learn mixed-gender socialization skills, which provide benefits in life-long success.

The factors remaining to be addressed are the forms of gender bias persisting in STEM classrooms. According to Acker and Oatley ${ }^{48}$, the perception that boys dominate classroom interactions and monopolize technology continues to influence teacher behaviour. Boys apparently behave in this way for two main reasons: they are more self-confident than girls in high school and typical school practices reward gregarious behaviours ${ }^{48}$. Claude Steele ${ }^{49}$ succinctly summarizes the challenge women face in having to overcome stereotypes:

To continue in math, for example, a woman might have to buck the low expectations of teachers, family, and societal gender roles in which math is seen as unfeminine as well as anticipate spending her entire professional life in a male-dominated world.

Finally, it is important to note that the academic researchers cited in this paper only discuss behaviour trends. Not all women had negative experiences in science classrooms or family-based gender role expectations, but significant proportions $\mathrm{do}^{50-52}$. Perhaps if teachers take time to learn about each student's personal strengths ${ }^{53}$, they will successfully transform their science classrooms into safe venues that inspire all students to freely explore and discover how to apply science to make the world a better place. 
Trends of physics participation and post-secondary transitions in British Columbia

British Columbia is the westernmost province in Canada, and has a population of approximately 4.6 million people. The fifteen publicly funded colleges and eleven publicly funded universities, only five offer engineering diplomas and degrees and only four over comprehensive postsecondary training. Privately funded colleges and universities in $\mathrm{BC}$ have narrower mandates. Camosun College has the broadest range of courses and programs, many of which transfer into degree programs at the universities. Data from Camosun, therefore, provides a comprehensive set, including both breadth of high school student applicants and breadth of programs. In other words, this data set provides a general picture of the British Columbia student body.

A complete analysis of $\mathrm{BC}$ data is optimal however acquiring the data from the universities has been problematic to date. I continue to pursue this data for inclusion in future papers.

Camosun College was formed in 1972 and has kept electronic student grades since that time. Although early data is sparse due to small start-up class sizes and the small number of programs offered, the current student population as of 2014 is more than 10,000 full time equivalent students. This provides a good number for trending correlations.

Interestingly, $46 \%$ of students at Camosun who have high school physics credits are female. Yet women comprise less than 5\% of engineering students. The table in Figure 1 depicts the correlations between the percentage of women with high school physics credits and the corresponding feminization of curriculum. The table in Figure 2 depicts the career transition patterns of women and men with high school physics credits.

[This section is in work. I have acquired the data from a comprehensive college in Victoria, British Columbia, Canada, and am in the process of analyzing this data for

- $\quad$ trends in girls' participation in high school physics classes

- $\quad$ program transitions choices of girls with high school physics credit

The purpose of the transition analysis is to determine which careers girls in physics are pursuing. This analysis is to be complete and ready for inclusion in this paper by April 2015.]

\section{Next Steps}

This review presented feminist influences on curriculum over the past few decades and the corresponding statistical information based on the analysis of college student data. Educational change has been shown to improve the wellbeing of society by provoking discussions about issues and events that had major impacts on society ${ }^{54}$. As indicated by the data analysis, there is much that still needs to be done to reducing the perceived barriers for women to enter careers in applied physical science. Future changes to curriculum will generate new topics of debate depending on how those changes manifest. Surveys of the perceptions of BC high school physics students today may reveal new information about how these perceived barriers to careers in the applied physical sciences continue to evolve. A survey of physics textbooks approved by the British Columbia Ministry of Education over this same temporal period may demonstrate how feminism has influenced and been influenced by science curriculum design. Possible changes to 
curriculum and lesson plans may provide opportunities to include more girls in scientific conversations; this may become clearer through the analysis of the participation rates of girls in science. As shown by the data analysis, too, is the interesting indication that correlations may exist between the evolution of feminized high school physics curricula and participation rates of girls in post secondary physics programs.

Changes to education over the last century and a half have come about as a result of changes in the way society views itself. Recognition of gender inequalities led to critical reviews of teaching materials, curriculum documents and textbooks, that identified the perpetuation of biases ${ }^{12,10,9}$. Adding commentary on the historical influences of women on the content, be it history or mathematics, and practice problems examples that reflect women's experiences teach students that the female curriculum content is relevant to the academic future of boys and girls ${ }^{6,30}$. But it is not enough to merely change the tools: teacher perceptions and behaviours must mirror the changing curriculum. Unfortunately, this takes much longer to come about but is another future project that may prove to be quite effective in improving the retention of women in the applied physical sciences.

\section{References}

1. Canadian Engineers for Tomorrow: Trends in engineering enrolment and degrees awarded 20082012.1-58 (2013). at <http://www.engineerscanada.ca/sites/default/files/enrolment_report_2012_eng.pdf>

2. Dyson, J. James Dyson : Canada has a serious shortage of engineers. The Globe and Mail 1-2 (2013). at <http://www.theglobeandmail.com/globe-debate/james-dyson-canada-has-a-serious-shortage-ofengineers/article10969556/>

3. Ivie, R. \& Ray, K. N. Women in Physics and Astronomy, 2005. American Institute of Physics 124 (2005). at <http://swps.berkeley.edu/SWPS101_2013/refAIPreport05.pdf>

4. Levin, M., Xie, Y., Shauman, K. A., Ray, K. N. \& McDonnell, F. Why so few choose physics : An alternative explanation for the leaky pipeline. Am. J. Phys. 73, 583-586 (2005).

5. Adshade, M. Female labour force participation in an era of organizational and technological change. Can. J. Econ. Can. d'économique 45, 1188-1219 (2012).

6. Briskin, L. \& Coulter, R. P. Introduction Feminist Pedagogy: Challenging the normative. Can.J. Educ. 17, 247-263 (1992).

7. Cherubini, L., Hodson, J., Manley-Casimir, M. \& Muir, C. ' Closing the Gap“ at the Peril of Widening the Void: Implications of the Ontario Ministry of Education"s policy for Aboriginal education. Can.J. Educ. 33, 329-356 (2010).

8. Gaskell, J. Gender matters from school to work. Resour. Fem. Res. 23, 49-50 (1994).

9. Pomerantz, S., Raby, R. \& Stefanik, A. Girls Run the World? Caught between Sexism and Postfeminism in School. Gend. Soc. 27, 185-207 (2013).

10. Pomerantz, S. \& Raby, R. “Oh, she's so smart”: girls' complex engagements with post/feminist narratives of academic success. Gend. Educ. 23, 549-564 (2011). 
11. Gaskell, J. \& Rubenson, K. Educational outcomes for the Canadian workplace. (University of Toronto Press, 2004).

12. Gaskell, J. The influence of the feminine role on the aspirations of high school girls. 344 (1973). at $<$ http://www.worldcat.org/title/influence-of-the-feminine-role-on-the-aspirations-of-high-schoolgirls/oclc/17887301>

13. Coulter, R. P. \& Greig, C. J. The Man Question in Teaching: An historical overview. Alberta J. Educ. Res. 54, 420-431 (2008).

14. Clark, P. "A nice little wife to make things pleasant:" Portrayals of women in Canadian history textbooks approved in British Columbia. McGill J. Educ. 40, 241-265 (2005).

15. Clark, P. Clio in the curriculum: The jury is out. Can. Soc. Stud. 32, 45-48 (1998).

16. Franzosa, S. D. Reconceptualizing Curriculum Transformations. NWSA J. 10, 154-161 (1998).

17. Mujawamariya, D. \& Hamdan, A. Appropriately Diverse ? The Ontario Science and Technology Curriculum Tested Against the Banks Model Précis. Can. J. Educ. 36, 416-448 (2013).

18. Gaskell, J. Creating school choice: The politics of curriculum, equity and teachers' work. Can. Public Policy 28, 39-50 (2002).

19. Bird, F. et al. Report of the Royal Commission on the Status of Women in Canada. 1-473 (1970). at <http://epe.lac-bac.gc.ca/100/200/301/pco-bcp/commissions-ef/bird1970-eng/bird1970-eng.htm>

20. Brown, G., Western, D. \& Pascal, J. Using the F-Word: Feminist Epistemologies and Postgraduate Research. Affil. J. Women Soc. Work 28, 440-450 (2013).

21. Riley, D. Hidden in plain view: feminists doing engineering ethics, engineers doing feminist ethics. Sci. Eng. Ethics 19, 189-206 (2013).

22. Coulter, R. P. Anti-Racism, Feminism and Critical Approaches to Education. Can. J. Educ. 21, 219-220 (1996).

23. Gaskell, J. Course Enrollment in the High School: The Perspective of Working-Class Females. Sociol. Educ. 58, 48-59 (1985).

24. Anderson, D. Status of Women. The Canadian Encyclopedia 1-11 (2014). at <http://www.thecanadianencyclopedia.ca/en/article/status-of-women/>

25. Clark, P. Clio in the Curriculum: Vindicated at Last. Can. Issues 42-46 (2013). at <Clahttps://ezproxy.royalroads.ca/login?url=http://search.proquest.com/docview/1443919271?accountid=8056>

26. Gaskell, J. Educational change and the women's movement: Lessons from British Columbia schools in the 1970s. Educ. Policy 18, 291-310 (2004).

27. Gaskell, J. Counseling Girls for Equal Opportunity. Sch. Guid. Work. 39, 35-38 (1983).

28. Coulter, R. P. And Academic Sexism Too: A comment on The Bell Curve. Alberta J. Educ. Res. 41, 308-311 (1995).

29. Coulter, R. P. Struggling with Sexism: Experiences of feminist first-year teachers. Gend. Educ. 7, $33-50$ (1995). 
30. Seegars, G. \& Boekaerts, M. Gender-Related Differences in Self-Referenced Cognitions in Relation to Mathematics. J. Res. Math. Educ. 27, 215-240 (1996).

31. Li, Q. Beliefs and Gender Differences: A New Model for Research in Mathematics Education. Interchange 35, 423-445 (2004).

32. Smith, D., Bourne, P.\& McCoy, L. Girls and schooling: their own critique. Resour. Fem. Res. 26, 55-68 (1998).

33. Shapka, J. D. Trajectories of math achievement and perceived math competence over high school and postsecondary education: effects of an all-girl curriculum in high school. Educ. Res. Eval. 15, 527-541 (2009).

34. Eccles, J. S. et al. Self-Concepts, Domain Values, and Self-Esteem: Relations and changes at early adolescence. J. Pers. 57, 283-310 (1989).

35. Frenzel, A. C., Goetz, T., Pekrun, R. \& Watt, H. M. G. Development of Mathematics Interest in Adolescence: Influences of Gender, Family, and School Context. J. Res. Adolesc. 20, 507-537 (2010).

36. Jacobs, J. E., Lanza, S., Osgood, D. W., Eccles, J. S. \& Wigfield, A. Changes in Children's SelfCompetence and Values: Gender and Domain Differences across Grades One through Twelve. Child Dev. 73, 509527 (2014).

37. Nagy, G. et al. The Development of Students' Mathematics Self-Concept in Relation to Gender: Different Countries, Different Trajectories? J. Res. Adolesc. 20, 482-506 (2010).

38. Wigfield, A. et al. Change in children's competence beliefs and subjective task values across the elementary school years: A 3-year study. J. Educ. Psychol. 89, 451-469 (1997).

39. Watt, H. M. G. Development of Adolescents' Self-Perceptions, Values, and Task Perceptions According to Gender and Domain in 7th- through llth-Grade Australian Students. Child Dev. 75, 1556-1574 (2004).

40. Monkman, D. Science Curriculum Review Report. 91 (2001). at $<$ http://www.bced.gov.bc.ca/irp/pdfs/reports/scireview.pdf>

41. Nair, C. S. \& Fisher, D. L. Transition from Senior Secondary to Higher Education : A Learning Environment Perspective. Res. Sci. Educ. 30, 435-450 (2000).

42. Raby, R. \& Pomerantz, S. Playing it down/playing it up: girls' strategic negotiations of academic success. Br. J. Sociol. Educ. 1-19 (2013). doi:10.1080/01425692.2013.836056

43. U of T Engineering celebrates record number of female first-year students. $U$ of T Engineering News 1-6 (2015). at <http://news.engineering.utoronto.ca>

44. Vingilis-Jaremko, L. How Science Clubs Can Support Girls’ Interest in Science. Learn. Landscapes 3, 155-160 (2010).

45. Shapka, J. D., Domene, J. F. \& Keating, D. P. Trajectories of Educational Aspirations Through High School and Beyond: A Gendered Phenomenon ? Can. J. Educ. 35, 239-258 (2012).

46. Little, A. J. \& León de la Barra, B. a. Attracting girls to science, engineering and technology: an Australian perspective. Eur. J. Eng. Educ. 34, 439-445 (2009).

47. Shapka, J. D. \& Keating, D. P. Effects of a Girls-Only Curriculum During Adolescence: Performance, persistence, and engagement in mathematics and science. Am. Educ. Res. J. 40, 929-960 (2003). 
48. Acker, S. \& Oatley, K. Gender Issues in Education for Science and Technology: Current situation and prospects for change. Can.J. Educ. / Rev. Can. l'éducation 18, 255-272 (1993).

49. Steele, C. M. A Threat in the Air: How stereotypes Shape Intellectual Identity and Performance. Am. Psychol. 52, 613-629 (1997).

50. Fouad, N. A. \& Singh, R. Stemming the Tide: Why women leave engineering. 1-64 (2011).

51. Fouad, N. A. Leaning in, but Getting Pushed Back (and Out). 1-39 (2014). at <http://www.apa.org/news/press/releases/2014/08/pushed-back.pdf>

52. Tarnai-Lokhorst, K. V. Gender Balance in Engineering: Is this an issue worth pursuing? Innovation 18, 26-29 (2014).

53. Brickhouse, N. W., Lowery, P. \& Schultz, K. What Kind of a Girl Does Science? The Construction of school science identities. J. Res. Sci. Teach. 37, 441-458 (2000).

54. Gaskell, J. Learning from the women's movement about educational change. Discourse Stud. Cult. Polit. Educ. 29, 437-449 (2008).

\section{Katherina V. Tarnai-Lokhorst}

Kathy is a Mechanical Engineering Instructor at Camosun College. She received her BASc from the University of British Columbia in 1987 in mechanical engineering, specializing in aerodynamics, and her MBA from the University of Phoenix in 2007. Kathy is pursuing her Doctor of Social Science at Royal Roads University, researching educational philosophies and practices prevalent in high school and introductory university physics courses; her focus is to increase gender diversity in engineering education and the engineering profession. Kathy is an elected Councillor for APEGBC (the Association of Professional Engineers and Geoscientists of British Columbia) and has served on several academic and corporate governance committees. 